\title{
INFORMATIZATION OF MODERN SOCIETY AND ITS SOCIO-ECONOMIC CONSEQUENCES
}

\author{
Ukrainian State University of Chemical Technology, Dnipro, Ukraine
}

\begin{abstract}
Was analyzed the essence of the global process of informatization of society and approaches to the analysis of its socio-economic consequences are investigated. Had determined that informatization of society produces not only positive effects from the point of view of ensuring the progressive movement of society through progress, but also carries certain threats. In addition, was proven, that informatization of society manifests itself in all spheres of a holistic social system. Consequently, given the contradictory and non-linear nature of this phenomenon to ensure the realization of the needs of man, nature, society and future generations, was underlined the necessity of carrying out a comprehensive study of both positive and negative manifestations of informatization in terms of all subsystems of the social system - economic, social, socio-cultural, political, legal and scientific. The results have been obtained through the use of methods: abstraction - in determining the essence of the category «informatization of society»; general and special - in establishing the unity of existing approaches in the study of the consequences of the process of informatization for man, nature, society and future generations; system analysis - in determining the components of the social system and the study of the impact of informatization on each of them. Proceeding from the characteristics of informatization as a global, multivector, complex and contradictory process, as well as considering the multifaceted forms of its manifestation, the important task of the state, civil society and the whole world community is to enhancement of positive effects and leveling threats which informatization is producing in all major spheres of socio-economic system to ensure the realization of human needs, the society of nature and future generations.
\end{abstract}

Keywords: informatization of society, informational economy, information and communication technologies, socio-economic system, positive displays of informatization, negative manifestations of informatization.

DOI: $10.32434 / 2415-3974-2019-9-1-13-23$

\section{Introduction and problem statement}

The formation of a post-industrial society, which in the scientific literature has also been called "technetronic era", "information-oriented society", "digital economy", etc., has led to a radical change in the sources and factors of economic growth and development of society. In the new type of economy, unlike the industrial mode of management which is based on the priority use of natural and capital resources, the main source of social progress appears to be information and knowledge. It is important to note that the uninterrupted production and dissemination of new knowledge as well as its practical use, is impossible without a well-developed information infrastructure, that is, information systems, information networks, various channels and ways of transmitting information.

It is the rapid development of the above industry in a new era that formed the basis of information society formation owing to the process of informatization which is understood by the scientists as «a set of interrelated organizational, legal, political, socio-economic, scientific and technological, production processes aimed at creating conditions for satisfying information needs of citizens and society on the basis of the creation, development and use of information systems, networks, resources and information technologies created on the basis of applyng modern computing and communication technology [1]. Consequently, in the leading

(C) Fedorova N.Ye., 2019 
countries of the world, information and communication technologies (ICT) are now developing at an extremely rapid pace as a result of using the current methods of redistribution of national income (NI) at which a significant proportion of financial resources is invested in the appropriate industry. For example, in the United States, one third of annual gross domestic product (GDP) growth and $75 \%$ of added value in industry are due to the use of modern information technology. In the information sector of this country, which accounts for $25 \%$ of all R \& D expenditures, the number of employed in the last decade has doubled [2].

The rapid development and dissemination of ICT is assuming the character of an unprecedented of its scope information revolution which fundamentally changes the established principles and methods of management and also influences all other subsystems of the social system: ecological, political, legal, socio-cultural, etc.

By contributing to the development of a qualitatively new socio-economic environment in which information and knowledge become the main source of competitive advantages both at the firm level and at the level of the national economy, informatization is a complicated and controversial process. In fact, acting as a destabilizing factor in relation to the social system, it manifests itself in the form of aggravation of both positive and negative social phenomena, enhances existing ones and creates a number of new specific threats to progressive socioeconomic development of society. In view of the scale of social transformations as a result of society informatization, the problem of studying its positive and negative consequences for society as a whole, nature and future generations becomes most urgent.

\section{Analysis and research of recent publications}

In modern scientific literature, the problem of forming foundations of post-industrial civilization through informatization has recently become unprecedented timeliness. Thus, in the works of B. Apsher, K. May, V. Osadchy, L. Marchuk, V. Pleskach, A. Sazonets, L. Fedulova, O. Shnipko and others, the general laws of the informatization process, its concrete forms of manifestation and social consequences are analyzed. At the same time, the analysis of this problem performed by modern scientists is not, in general, distinguished by its complexity, the scientists concentrating on separate aspects of the manifestation of these transformations. For example, the problems of the efficiency of state management, the acceleration of the rate of scientific and technological progress, the development of hightech industries and high technologies are associated with the informatization [3, p.89], that is, there is a focus on the political, economic and scientific aspects of social development. Among the positive manifestations of informatization, the scientists also note the promotion of productivity growth, scale of movement of goods and capital, improved economic governance, democratization of society, the development of science-intensive production and high technologies, the enrichment of spiritual life $[4,53]$, that is, economic, political, scientific, sociocultural aspects of informatization is analyzed.

Some scholars also include ensuring of fast processing of economic information, acceleration of goods realization through e-commerce, transformation of consumers into participants of innovation activity, acceleration of international integration of financial activity, transition to openness of management, dramatic changes in the education system, creation of the conditions for employment problem solution, strengthening of society consolidation as a result of virtual communication, increase of social intelligence as a whole, promoting preservation of the environment [5] to the consequences of informatization. So, the economic, political, social, ecological and socio-cultural aspects of the phenomenon involved are covered.

There are also scientific works in which not only the positive, but also the negative aspect of informatization is investigated. In particular, it is noted that informatization can contribute to aggravating the problems of «digital divide», especially for developing countries and for countries with transformation economies. Such negative aspect of informatization as informational warfare is also observed [6].

Comprehensive investigation of informatization consequences was carried out by the Swiss researcher Ch. Hessing who has analyzed four areas of information use: culture and society, politics, economy and labor, international relations. For each of these spheres, both positive and negative consequences of society informatization were identified [7, 217]. However, this analysis, in our opinion, is not sufficiently comprehensive. Thus, it uses rather unsuccessful approach to distinguishing the main spheres of the social system which is limited only to four elements. In addition, in our opinion, international relations are an integral part of both «economy and labor» and «politics» subsystems. Because of this, in the given investigation the consequences of informatization are not systematized distinctly. For example, the author attributes such positive consequences of informatization as «environmental protection» to the subsystem «economy and labor» while it is obvious that this aspect of social progress is manifested more in the environmental sphere of the social system which is not singled out by the author into an independent subsystem at all. In addition, such consequences as «ever growing difficulties of life», «stresses» are 
considered by the author among those belonging to the above mentioned subsystem and which, in our opinion, corresponds to the characteristics of subsystem «culture and society».

Consequently, the rapidity and contradiction of informatization process, from our point of veiw, necessitates a deeper analysis of this process regularity at the level of the social system and its individual segments.

\section{The purpose of the article}

The purpose of the article is to analyze positive and negative consequences of informatization for the modern socio-economic system and its subsystems.

\section{Presentation of the main research material}

It is our belief that in order to carry out a holistic analysis of informatization consequences for the social system it is necessary to adhere to clear principles of structuring the given system, which is based on using the fundamentals of general systems theory as well as structural and functional analysis, which allow us to single out it within six main subsystems: economic, environmental, political and legal, social, socio-cultural and scientific. Economic subsystem is represented by a set of social relations concerning production and consumption; social subsystem represents social interactions, that is, the interaction of various social groups with regard to the conditions of their life. Socio-cultural subsystem is a complex of interactions and relationships established in the process of joint practical and spiritual activity of people about the use of all the material and spiritual values; ecological subsystem combines the system of social relations associated with the use of nature resources. Political and legal subsystem is connected with the functioning of the state institution of public relations management in order to harmonize the interests of society and its separate groups, to realize long-term interests of society. Scientific subsystem combines social relations between the subjects of the scientific process with regard to production, distribution and practical application of new knowledge about the objective laws of the functioning and development of society in order to change the environment in accordance with the needs and interests of mankind [8], [9]. The proposed method of structuring the social system provides an opportunity for more precise and holistic analysis of positive and negative consequences of informatization for all its main components since each of the subsystems of the social system has a certain specificity of its functioning which determines the special nature of the processes occurring within it due to the external influences of sociosphere.

Thus, in the economic sphere, the ICT dissemination, information gain and its free distribution reduces transaction costs, promotes rationalization of business decisions. The introduction of modern information technology affects the improvement of existing processes and technology, the development of production relations, distribution, exchange and consumption. So, today, in the USA sales volume via the Internet has exceeded 300 billion dollars, this volume being equal to that in the automotive industry of the USA. Only thanks to the Internet as long ago as the $20^{\text {th }}$ century there appeared more than 400 thousand new jobs. In Japan, within the next 15 years, the development of the information sector will create at least 2.5 million jobs, and in Western Europe - more than 6 million [10]. Technological progress is moving towards non-waste production, the use of cheaper artificial raw materials, renewable energy sources, and unmanned production on the basis of production process intensification. All this increases the efficiency of social production process and results in decrease of product price with improving its quality, which ultimately contributes to more complete satisfaction of public needs.

The development of modern information technology promotes increasing the share of savings and accumulation through the growth in the efficiency of banking sector and non-bank financial institutions functioning. Due to the acceleration of informatization and ICT improvement, the investment process is intensified and the intellectual product is actively introduced the share of which in the finished product is constantly increasing. The progress of communications contributes to the growth and complication of social needs through accelerating information transfer among consumers in the conditions of market mechanism and competition.

At the same time, informatization of social life puts forward new economic threats to society. First, the reorientation of the labor market to the priority use of creative and intellectual labor puts forward new demands for the bearers of this resource, which may not correspond to the available labor force. This aggravates the problem of unemployment, especially among the senior citizens, who are less capable of retraining, as well as among people with mental abilities below the average level which gives rise to anxiety of workers and uncertainty about the future among the workers. Secondly, the personification of social production, which accompanies informatization, creates new economic problems: the production involved is relatively more expensive than standardized one, and its small volumes do not allow receiving significant profits. Therefore, at present, developed countries, especially the United States, in contrast to European countries, are trying not to suppress large-scale production in the modern conditions, but to take advantage of it, especially in the field of technology-intensive industries and technical innovations. So, at the beginning of the XXI century US businessmen have focused on 
creating and producing mass products that meet the requirements of post-industrialism, for example, replication of computer programs and other elements of informational support. In addition, while strengthening the economic relationship between individual subjects, regions and countries, the improvement of communications leads to a qualitative transformation of social life internationalization into globalization, which is of a contradictory nature, that is, it has both advantages and disadvantages for the development of national economic complexes of individual countries. Thus, informatization aggravates the problem of economic development cyclicality: in the conditions of forming a global technological space, the factors of asymmetric cyclic character in highly developed countries of the world are the acceleration of innovations diffusion and synchronization of technological changes. As a result, there is a replacement of equipment and technologies generations, technological processes and the rhythm of cyclic economic dynamics is reduced. All this leads to an increase in the cost of updating processes and technology under the pressure of competitive struggle. In addition, the growth of the role of financial sector in modern economy under the influence of ICT development, which contributes to the increase of the efficiency of accumulation and investment, has an reverse side as well increasing the risk of financial crises due to the growth of speculative operations in this sector and the virtualization of the economy.

In the environmental sphere, informatization and the use of high technology allows to satisfy the needs of the society more fully with reduced impact, which is conditioned by the increasing economic efficiency of the final products production. The latest scientific developments and introduction of highperformance technologies permit to increase the efficiency of using non-renewable natural resources or to refocus on applying renewable sources of raw materials and energy, thereby reducing ecosystem load. At the same time, the globalization of public life which accompanies informatization leads to aggravation of global environmental problems. For example, carbon dioxide emissions from fossil fuels increased by $80 \%$ from 1970 up today. The extraction of raw materials in the world over the past 30 years has increased by $94 \%$, growth rate has been increasing since year 2000 [11].

In the social sphere, informatization can be seen as a factor contributing to reducing inequality, improving health and increasing life expectancy. Thus, Russian Academician S.P. Kapitsa says that, since the development of the information field in the broad sense (customs, beliefs, skills and knowledge transmitted from generation to generation when teaching or bringing up a person as a member a society) determines the pace of socio-economic development, stabilization of the population size and the harmonization of relations between nature and humanity will take place only as a result of information revolution and the building a society of knowledge [12].

Due to progress of ICT, there is a radical change in the principles of the redistribution of GDP. In the new conditions of increasing the value of information and knowledge, there occurs an increase in revenues or profits of innovators since they create a new product which according to the law of decreasing marginal utility has the greatest utility due to its rarity and uniqueness. Thus, the social and economic role of the entrepreneur increases, and a scientific product that can be used as innovations becomes more expensive increasing the income of its owner. This, in turn, changes the attitude of a person towards information in the direction of which the consumption shifts, which stimulates the generation of new knowledge. Thus, nowadays, out of a million of the richest Americans, more than $40 \%$ are people of creative professions, doctors, scientists and lawyers, the other $60 \%$ are hired managers of large companies, $2 / 3$ of which are bachelors or doctors of sciences [13]. The new basis for the social status of a person is not the things which a person has, but what he can - whether he is capable of transforming the information available to him into his own knowledge and use it. Consequently, in modern conditions there is a change in the ratio of sources of power in society in favor of knowledge.

At the same time, the development of the information society, the dissemination of information and knowledge do not only lead to the elimination of acute socio-economic problems, but also produces new threats: there is a stratification of society on an intellectual basis, which can be regarded as manifestation of inequality or discrimination. Such well-known authors as D. Bell, J.K. Galbraith, R. Darendorf and others point out that the new social group, which is referred to as «the underclass» by them, forms the specific sphere of existence of people excluded from the former type of social interaction $[14,27]$. Thus, the main reason for the class division of modern society is education and knowledge possession. As the Russian researcher V. Inozemtsev writes, «this paradox, as sad as it sounds, is entirely explained by the logic of the social systems development and the nature of such inequality and its deepening is concealed in the ingrained differences of people in terms of their abilities and talents, and, consequently, in the potential opportunity to achieve success in the field of production based on acquisition and application of new knowledge «[15, 28-29]. It is 
this phenomenon that seems most characteristic of modern society and at the same time very dangerous. All previously known principles of social distribution, based on property or position in the bureaucratic hierarchy, were much less rigid and to a much lesser extent conditioned by natural and personal factors. Meritocratic polarization of society is more rigid than class one since the qualities that enable a person to enter a "class of intellectuals" can not be inherited. Moreover, in the course of informatization, a new intellectual elite is formed who, in the conditions of inappropriate development of social spirituality, can use power in their selfish interests, which does not correspond to the characteristics of a democratic society. The paradox of the information age is that, despite the fact that information is the most democratic source of power because of a free access to it, at the same time it acts as the least democratic factor of production, since access to it does not necessarily mean possession of it.

Stratification in a new information society according to intellectual features takes place not only at the national level, but also at the supranational level. So, since in the period of formation of postindustrial civilization the main product of the production in the developed countries is information and knowledge, in the countries concerned there is no need to import raw materials and human labor, which are the competitive advantages of the backward countries. Similar processes in Western literature have been called «information and technological neocolonialism» which manifests itself in the tendency to reduce world prices for raw materials, to transfer «dirty» production from developed countries to peripheral ones, and so on. As a result, despite the increase in the various types of assistance from developed countries, the gap between them is increasing year by year. So, according to the Forbes magazine, the wealth of the richest people in the world for the period 2010-2016 has increased by $\$$ 0.5 trillion dollars and reached $\$ 1.76$ trillion. During this period, the half of humanity of modest means became impoverished by about $\$ 1$ trillion, that is, it lost $41 \%$ of its wealth. Approximately $2 / 3$ of the world's population live in poverty; today, developing countries account for almost $80 \%$ of the world's population and they produce only about $40 \%$ of the world GDP [16].

Since the main resource of the information economy is a person as a carrier of information and knowledge and ICT provides opportunities for free access to them, one of the reasons for intellectual differentiation and at the same time the result of this process is information or digital inequality (digital divide). On the one hand, digital inequality is generated by other forms of inequality that precede it; on the other hand, it may be the cause of deepening traditional forms of inequality. Therefore, it is possible to define this concept as «inequality in access to social, economic, educational, cultural and other opportunities that deepen as a result of unequal access to information computer technology» [17]. In this aspect, information inequality (or digital divide) represents unequal opportunities in terms of access and use of information and knowledge, as well as new technologies for development. This kind of inequality reflects a combination of common socio-economic problems and specific problems of insufficient infrastructure development, relatively high cost of access to it, weak development of national and local content, as well as the inability of the majority of people to benefit from information activities. Experts point out that digital inequality arise even in developed countries, in particular, the gap in the use of information technology for senior and younger generations, men and women, small and large businesses, residents of cities and those of remote areas, between countries, regions and even civilizations.

According to experts' estimates, the digital divide is not being reduced, but is constantly increasing. Many settlements, regions, and sometimes even entire countries do not have the resources to meet the basic needs of their citizens in education and health care. Central and South America, Africa are practically not covered by the Internet. The share of the African continent in the total number of Internet connections is only $0.25 \%$. In Central and South America, where there is a recent increase in the number of users of the World Wide Web, this increase is mainly due to three countries - Argentina, Brazil and Chile [18]. In 1999, New York had more Internet-subscribers than the whole of the African continent and South America taken together [19, 122-130]. Analyzing the growth rates of the poorest countries for the period from 2004 to 2009, the experts concluded that for mobile communication the digital gap between poor and rich countries is 7-9 years; for the Internet-communication - 17 years; for broadband communication - 15 years [20].

Digital inequality threatens serious economic losses. For example, according to the European Commission, if the EU measures to reduce digital divide prove to be successful, then in five years the European economy will grow by 85 billion euros. Annual growth will reach 17 billion euros - about $7.5 \%$ of the budget of the European Union [16].

The existence of digital inequality affects the change in the balance of power in the international arena, as it contributes to the formation of a new information culture in the community of nations, the establishment of a new world information order by these countries. Digital inequality is a field of 
interaction between states with different levels of information and communication equipment countries with a strong economy and developed institutions of power and law have limited preferences in the information sphere, while small and even backward states, which began to develop in the era of ICT emergence, were able to drastically break forth, give impetus to economic development and improve the well-being of their citizens. So, these countries do not need to invest heavily in technology, because they can take advantage of the achievements of leading countries by buying the products of communication technology there, including hardware and software. At the same time, they get the opportunity, avoiding intermediate stages of these products improvement, to use the most effective, advanced developments. These trends are getting significantly accelerated due to the processes of globalization during which the largest international corporations penetrating into the markets of developing countries become leaders of the dissemination of the latest advances in the information age.

Simultaneously, the development of infrastructure, cheapening of technology, increasing access and demand for ICT resulted only in the jumplike technological development of developing countries without changing their economic and social status. So, low- and middle-income countries can not overcome the digital barrier, despite steady growth, because only quantitative transformations that are not always qualitative, take place.

In socio-cultural sphere, as in other spheres, informatization of public life manifests itself ambiguously. On the one hand, free access to information is the human right stated in the UN Convention. The information- and cyberspace, which have reached the global level, promote in modern conditions more efficient and rapid dissemination of information, increase its accessibility. The informed person is more knowledgeable, better oriented in the environment and can make a better choice in all spheres of life. Information extends the horizons, that is, serves not only as economic, but also as cultural value, and satisfies the intangible needs of man. The progress of communications gives people freedom in both economic and socio-cultural spheres through the facilitation of the process of spatial motion, the possibility of distance work and education, the expression of personal opinion, and so on. The use of ICT for the most recent achievements in the educational process computerization, distance education, international seminars, webinars, etc. - facilitates access to educational services, especially for people with disabilities, which promotes the democratization of the educational process and increases its overall level.
At the same time, the mass of information increasing, it becomes rather difficult to process it and turn it into useful knowledge. The problem of selecting and filtering unnecessary or harmful information arises and intensifies. Increasing the speed of information transmission, acceleration of world economic processes results in physical and psychological overstrain of modern man. So, according to the WHO, nowdays every fourth or fifth inhabitant of the Earth suffers from mental disorders, and by 2020 depression will be the first among the diseases. Excess information, as well as its deficit, has certain dangers. Harmful information influence in modern literature was called «informational noise», which has signs of influence on the consciousness of individuals with the purpose of manipulating. An example of such manipulation is persuasive advertising, information of political and religious nature, etc. This problem is especially aggravated in the turning points of the state development, for example, during an election campaign. In addition, due to the excessive use of digital information technology, people may suffer information dependence, which can be compared to narcotic one. Thus, one of the characteristic modern trends is the progressive development of the forms, technologies and methods of influencing the consciousness (subconsciousness) and the mental state of man in comparison with the formation of effective mechanisms of counteraction to negative, destructive psychological influences.

It is important to note that the negative manifestations of society informatization are deepening under the influence of the tendencies towards globalization of socioeconomic life. Thus, as many researchers point out, the characteristic feature of the current stage of informatization is that having created a worldwide communications network, people have formed a world that is too complex for their intellectual capabilities and therefore they can not clearly understand and effectively predict the direction of their own development that creates additional threats to the existence of mankind and future generations.

In the political and legal sphere, the widespread use of ICT promotes democratization and optimization of the state management process. Thus, modern digital technologies allow fair and transparent elections to be held through the improvement of monitoring systems for conducting elections, which excludes the possibility of falsifications; to introduced electronic systems that make the government activities more transparent, allow it to be monitored by civil society and, at the same time, reduce expenditures for the financing of the state administration. Thus, a large number of state bodies sites, party structures, international non- 
governmental organizations containing various information continue to appear on the Internet, which can significantly increase the political awareness of users and give them an opportunity to express their opinion of a particular issue. For example, the system of «e-government» (electronic government) is an indispensable condition for building a knowledge economy and is an important criterion of democracy development. The indicator of the availability of «e-government» is monitored by international organizations (in particular, the World Bank) and serves as the basis for making up international ratings of the effectiveness of state regulation. The latest scientific achievements can help to legalize shadow capital and improve the system of control over the distribution of public funds. Automation and informatization of any business process can make it impossible or minimize illegal business operations, which increases the transparency of using capital, goods, and services of any origin and thus reduces the share of the shadow economy.

At the same time, the latest digital developments can serve as a means to introduce unfair political technologies and falsifications of both election results and the results of the government activity since human-generated electronic systems do not provide maximum protection from third-party intervention. It should also be noted that democracy as the power of majority cannot be most efficient in a society with low level of intellectual and spiritual development: in a democratic society, the political choice is made by the masses and that minimizes the influence of intelligent and far-sighted minority representatives as a «class of intellectuals».

In the early 1970"s, it was expected that using the latest information technologies in the near future people would be able to eliminate the disadvantages of the democratic process and contribute to the development of processes of global democratization. For example, the British prime minister (1997-2007), T. Blair stated: «I am convinced that the information revolution can breathe new life into our democracy.» However, the paradox is that not many people are enjoying the opportunities provided - the share of active Internet users, even in developed countries, is considerably inferior to the number of those who use traditional channels for receiving information, and even among them there is a very small group of those really interested in politics.

Comprehensive informatization of economic life as an attempt to minimize the share of shadow sector also has its own significant drawbacks: the transparency of market processes can be the reason for the increase in the number of those who want to avoid state control. The development of the shadow sector is also facilitated by the fact that the latest information technologies allow to hide large capitals from taxation, for example, through offshore zones. So, according to Forbes, in the period 2000-2014, the number of offshore investments increased fourfold; nine out of ten of the world's largest concerns are represented in at least one of the offshore zones [16].

Sinking into a cyberspace, the individual is more and more lose touch with real social life. Under conditions of freedom of the individual and information, the threat of increasing the influence of certain groups of people to others for selfrealization in the political or economic sphere through the information networks increases significantly - for example, before the elections. So, today, the cyberspace has become the habitat for a large number of different extremist groups. With the help of the latest information technologies, they, despite the geographical distance, easily establish contacts and coordinate their actions, which often end with those or other excesses. In the information age, even a single individual can play an important role in world politics and, independently or together with other individuals, challenge the most powerful states in the world. New technologies create the possibility of their unfair use by authoritarian political regimes. As a result, at the current level of development of the defense industry, there is a threat of the destruction of the entire world civilization.

Technical devices, through which the information influence on the person, society and state during the information confrontation is carried out, are called informational weapons. Theoreticians assign to this type of weapon a wide class of measures and means of informational influence on the enemy - from misinformation and propaganda to means of electronic warfare. The greatest danger of "information weapon" is that its use is impersonal and easily masked under protection measures. It is hardly possible to prohibit the development and use of information weapons as it is done with regard to chemical or bacteriological weapons. It is also impossible to limit the efforts of many countries to form a single global information space. Today, as a result of awareness of the dangers of information weapons, the term «Strategic Information Confrontation» appeared which means the states' using the global information space and infrastructure to conduct strategic military operations and reducing the impact on their own information resource. Strategic information confrontation is an independent, fundamentally new kind of strategic confrontation, able to initiate conflicts without using armed force [21]

Another important problem that accompanies the process of society informatization is the emergence and development of a new form of crime - cybercrime characterized by the use of information 
space as an instrument of unlawful acts. Cybercrimes are characterized by the following features: high latency, the complexity of their detection and investigation, the transnational character, the complexity of evidence in the courts of such cases, high damage even from a single crime. In this regard, effective control over cybercrimes require more intensive international cooperation than existing measures to combat any other form of transnational crime.

One of the most dangerous types of cybercrime is intellectual property rights violation which has become widespread in the era of informatization. Legal protection of intellectual property rights is a financial incentive needed to invest in technological development. Accordingly, countries with insufficient levels of it can not attract significant volumes of investment and technological flows. As a result, stratification of countries in terms of production and sales of high-tech products is increasing - according to the UN, the modern market of high-tech products is divided as follows: Western Europe - 35\%, USA -25 , Japan $-11 \%$, Singapore $-7 \%$, Korea $-4 \%$, China $-2 \%$, other countries together $-16 \%$, Ukraine - about $0.04 \%$ [22].

The problem of copyright protection in the most expressive form is manifested in the Internet, which is primarily due to the simplicity and speed of information layout on the World Wide Web, without the need for mandatory authorization, openness and availability of using electronic resources by practically unlimited circle of persons. Consequently, with its high attractiveness, the Internet network becomes a virtual market for turnover and sales of products with violation of the exclusive rights of authors. Today, the most common violations of copyright are the distribution of pirated copies of programs and works in digital form, the guarantee of copyright in global computer networks.

Computer piracy as a form of copyright infringement on the Internet continues to slow down global economy, IT-innovation and job creation. The International Intellectual Property Alliance on February 7, 2013 published a report with recommendations on the official website www.iipa.com/. It covered 48 countries, among which special attention was paid to Ukraine. The average piracy rate in the world is $42 \%$, with the highest rates characteristic of developing countries [23]. It is quite natural that violations in the software market are inherent not only of our country but also of many countries of the world, but a high level of economic development, considerable scientific and technical potential as well as regulated mechanism of legal protection of software, although does not lead to the avoidance of «piracy «as such, but allows it to be kept at a rather low level - an average of
25-37\% in the United States and Japan and at 68\% in Europe [24].

Influence of informatization on the scientific subsystem is manifested in the fact that due to the progress in the field of ICT, in particular, in the system of accumulation and transmission of information, the mass of knowledge increases, which in turn serves as the foundation for further scientific discoveries. With the application and dissemination of scientific type of thinking in society, the number of those for whom this field of activity becomes attractive is growing. Thus, taking into account the fact that information and scientific knowledge has a special nature of alienation, the development of science contributes to the accumulation of a basis for a scientist to further making his scientific discoveries (due to the growth of the quality of his own intellectual capital) and the prospects for increasing the scientific product at his disposal. This can create a stable source of income for a scientist and reliably protect his welfare.

The transformation of science and knowledge into productive force makes correlation between scientific activity and welfare obvious, increases social status of their carriers. This, in turn, this changes the attitude of a person towards information in the direction of which the consumption shifts, which stimulates generation of new knowledge. Thus, nowadays, out of a million of the richest Americans, over $40 \%$ are people of creative professions, doctors, scientists and lawyers, the other $60 \%$ are hired managers of large companies, $2 / 3$ of whom are bachelors or doctors of sciences [25]. In addition, the improvement of technic and technology in a competitive environment raises the demand for a scientific product, which increases its price and profitability in the scientific field and serves as the basis for increasing its funding and correspondingly increasing the share of this sector in public production. Thus, the modern world market of hightech products is growing at a rate of 2-2.5 times faster than the growth rate of the world economy, and internal costs of research and development in developed countries are constantly increasing: in the EU countries from 2002 to 2012 their volume increased by $42.9 \%$, while the level of R \& D expenditures in the business sector was: $1.3 \%$ of GDP in the EU (2012); $2.49 \%$ in Japan (2010); $1.83 \%$ in the US (2011) [2].

At the same time, the rapid development of scientific field as a result of society informatization is far from guaranteeing that the latest scientific discoveries will be used in the interests of man, nature, society and future generations.

\section{Conclusions}

The process of informatization causes qualitative changes in all spheres of public life forming the 
contours of the future post-industrial society. The rapid spread of computer technology, unprecedented opportunities for the transfer and reception of information, expanding opportunities for social development, simultaneously lead to serious socioeconomic consequences for man, nature, society and future generations. Proceeding from the characteristics of informatization as a global, multivector, complex and contradictory process as well as the multifaceted forms of its manifestation, the important task of the state, civil society and the whole world community is to enhance these positive effects and leveling the threats which are generated by informatization in all major spheres of socioeconomic system.

\section{REFERENCES}

1. Zakon Ukrainy «Pro Natsionalnu prohramu informatyzatsii». Stattia 1 [Law of Ukraine on the National Program of Informatization. Vol. 1] (1998). Retrieved from https:/ /zakon.rada.gov.ua/laws/show/74/98/.

2. Networked Readiness Index. Retrieved from http:// reports.weforum.org/global-information-technology-report/.

3. Ocadchyi V.V. (2008). Improvement of professional training of future teachers by means of computer-oriented training system // Informatsiini texnolohii v ocviti - Informational Extensions in Education. - 2008. - Vol. 2. - P.90-94.

4. Mei K. (2004). Information society: Ceptic View. Kiev, 2004. -220 p.

5. Marchuk L.P. Modern informatization of society and its impact on innovation processes // Visnyk ahrarnoi nauky Prychornomoria - Bulletin of agrarian science of the Black Sea region. - 2012. - Vol. 1. - P.37-44.

6. Stadnichenko $O$. Informatization as a factor in the development of society and the state. - Retrieved from http:// oldconf.neasmo.org.ua/node/2683/

7. Rakytov A.I. Philosophy of the Computer Revolution. Moskva: Polytyzdat, 1991.

8. Fedorova N.Ie. The essence of science and its place in a social organization // Prychornomorski ekonomichni studii Black Sea Economic Studies. - 2018. - Vol. 26/1. - P.10-15.

9. Fedorova $N$. Socio-Economic consequences of the Impact of Science on the Development of Society // Modern Science - Moderni veda. Praha, Ceska republica, Nemoros. 2018. - Vol. 1. - P.19-26.

10. Supyan $V$. (2001). Labor in the USA: New Trends and Challenges of the XXI Century. - Retrieved from http:// vasilievaa.narod.ru/17_3_01.htm.

11. Giljum S, Dittrich M., Lieber M, Lutter S. (2014). Global Patterns of Material Flows and their Socio-Economic and Environmental Implications: A MFA Study on All Countries World-Wide from 1980 to 2009. Retrieved from http:// www.mdpi.com/2079-9276/3/1/319/pdf.

12. To knowledge societies. UNESCO World Report. Preface. K. Matsuura/ - Retrieved from https://www.ifap.ru/ library/book042.pdf.

13. Ladychenko T.V (2009). World History. - Retrieved from https://www.geneza.ua/sites/default/files/product-images/ pdf.

14. Bell D. The World and the United States in 2013. Daedalus. - 1987. - Vol. 116 (3). - P.1-31.

15. Inozemtsev V.L. Technological progress and social polarization in the XXI century // Politicheskie issledovaniya Political studies. - 2000. - Vol. 6. - P.28-39.

16. Forbes Ukraina. Retrieved from http://forbes.net.ua/.

17. Rzhevska N.F. (2010), Strategic forecasts to overcome information inequality in a globalizing environment]. Retrieved from http://jrnl.nau.edu.ua/index.php/IMV/article/viewFile/ 3079/3025.

18. Vaynshteyn $G$. The Internet as a factor of social transformations // Mirovaya ekonomika i mezhdunarodnyie otnosheniya - World economy and international relations. 2002. - Vol. 7. - P.16-27.

19. Martyinov V.A., Dyinkin A.A. The world at the turn of the millenniums (the forecast of the development of the world economy until 2015). - Moscow: Novyiy vek, 2001. - 592 p.

20. Global ICT Statistics on Internet Usage, Mobile, Broadband: 1998-2009. Retrieved from http://en.wordpress.com/ tag/ict4d-statistics-2//2010/09/16/globalict-statistics-on-internetusage-mobile-broadband-1998-2009/.

21. Views of US military experts on information confrontation // ZVO. - 2001. - Vol. 8. - P.10-15. - Retrieved from http://militaryarticle.ru/zarubezhnoe-voennoe-obozrenie/ 2001-zvo/6727-vzgljady-voennyh-jekspertov-ssha-na-vedenie [in Russian].

22. Osetskyi V.L. (2009). Foreign experience of protection and stimulation of the development of intellectual property in Ukraine] - Retrieved from http://www.nbuv.gov.ua/old_jrn/ Soc_Gum/Se/2009_1/09ovfeoi.pdf [in Ukrainian].

23. Fedulova L.I., Androshchuk H.O., Khaustov V.K. Intellectual property in the national innovation system // National Academy of Sciences of Ukraine, Institute of Economics and Forecasting. $-2010 .-216$ p.

24. Pichkurova Z.V. (2010). Podolannia problem okhorony prohramnoho zabezpechennia v konteksti yevropeiskoi intehratsii ukraini: vitchyzniani realii ta mizhnarodnyi dosvid Overcoming Software Security Problems in the Context of European Integration of Ukraine: National Reality and International Experience. Naukovyi visnyk Instytutu mizhnarodnykh vidnosyn NAU. Seriia: ekonomika, pravo, politolohiia, turyzm - Scientific herald of the Institute of International Relations of the NAU. Series: economics, law, political science, tourism, 2/2. Retrieved from http:// jrnl.nau.edu.ua/index.php/IMV/article/view/3055.

25. History of the modern world. Chapter 15: Post-industrial society: emergence, development, perspectives. - Retrieved from http://www.history.vn.ua/book/suchasnogo/16.html.

Received: 05.04.2019

Reviewer: Prof. Dubnitskyi V.I. 


\section{ІНФОРМАТИЗАЦІЯ СУЧАСНОГО СУСПІЛЬСТВА ТА ІІЇ СОЦІАЛЬНО-ЕКОНОМІЧНІ НАСЛІДКИ \\ Федорова Н.С.}

Проаналізовано сутність загальносвітового процесу інформатизації суспільства та досліджено підходи до аналізу його соціально-економічних наслідків. Визначено, що інформатизація суспільства продукує не тільки позитивні наслідки з точки зору забезпечення поступального руху суспільства шляхом прогресу, а й несе в собі певні загрози. Окрім того, інформатизація суспільства проявляє себе в усіх сферах цілісної суспільної системи. Отже, зважаючи на суперечливий та нелінійний характер вказаного явища для забезпечення реалізаціі потреб людини, природи, суспільства й майбутніх поколінь, наголошено на необхідності здійснення комплексного дослідження як позитивних, так і негативних проявів інформатизації в усіх основних підсистемах суспільної системи - економічній, соціальній, соціокультурній, політико-правовій та науковій. Результати отримані за рахунок застосування методів: абстракції - при визначенні сутності категорії «інформатизація суспільства»; загального і особливого - при встановленні єдності існуючих підходів в дослідженні наслідків процесу інформатизації для людини, природи, суспільства й майбутніх поколінь, системного аналізу - при визначенні складових суспільної системи та дослідженні впливу інформатизації на кожну із них. Виходячи з характеристик інформатизації як глобального, багатовекторного, комплексного й суперечливого процесу, а також багатогранності форм його прояву, важливим завданням держави, громадянського суспільства та всієї світової спільноти виступає підсилення вказаних позитивних ефектів $і$ нівелюванні загроз, що продукує інформатизація в усіх основних сферах соціально-економічної системи для забезпечення реалізаціі потреб людини, суспільства природи й майбутніх поколінь.

Ключові слова: інформатизація суспільства, інформаційна економіка, Інформаційно-комунікаційн технології, соціально-економічна система, позитивні прояви інформатизації, негативні прояви інформатизації.

\section{ИНФОРМАТИЗАЦИЯ СОВРЕМЕННОГО ОБЩЕСТВА И ЕЕ СОЦИАЛЬНО-ЭКОНОМИЧЕСКИЕ ПОСЛЕДСТВИЯ}

\section{Федорова H.E.}

Проанализирована сущность общемирового процесса информатизации общества и исследованы подходы к анализу его социально-экономических последствий. Определено, что информатизация общества продуцирует не только положительные последствия с точки зрения обеспечения поступательного движения общества по пути прогресса, но и несет в себе определенные угрозы. Кроме того, информатизация общества проявляет себя во всех сферах целостной общественной системы. Итак, несмотря на противоречивый и нелинейный характер указанного явления для обеспечения реализации потребностей человека, природы, общества и будущих поколений, отмечена необходимость осуществления комплексного исследования как положительных, так и отрицательных проявлений информатизации во всех основных подсистемах общественной системы - экономической, социальной, социокультурной, политикоправовой и научной. Результаты получены за счет применения методов: абстракции - при определении сущности категории «информатизация общества»; общего и особенного - при установке единства существующих подходов в исследовании последствий процесса информатизации для человека, природы, общества и будущих поколений; системного анализа - при определении составляющих общественной системы и исследовании влияния информатизации на каждую из них. Исходя из характеристик информатизации как глобального, многовекторного, комплексного и противоречивого процесса, а также многогранности форм его проявления, важной задачей государства, гражданского общества и всего мирового сообщества выступает усиление указанных положительных эффектов и нивелирование угроз, которые продуцирует информатизация во всех основных сферах социально-экономической системы для обеспечения реализации потребностей человека, общества природы и будущих поколений.

Ключевые слова: информатизация общества, информационная экономика, информационнокоммуникационные технологии, социально-экономическая система, положительные проявления информатизации, негативные проявления информатизации.

\section{INFORMATIZATION OF MODERN SOCIETY AND ITS SOCIO-ECONOMIC CONSEQUENCES}

Fedorova N.Ye. *

Ukrainian State University of Chemical Technology, Dnipro, Ukraine

\section{*e-mail: sandetskaya777@ukr.net}

Was analyzed the essence of the global process of informatization of society and approaches to the analysis of its socioeconomic consequences are investigated. Had determined that informatization of society produces not only positive effects from the point of view of ensuring the progressive movement of society through progress, but also carries certain threats. In addition, was proven, that informatization of society manifests itself in all spheres of a holistic social system. Consequently, given the contradictory and non-linear nature of this phenomenon to ensure the realization of the needs of man, nature, society and future generations, was underlined the necessity of carrying out a comprehensive study of both positive and negative manifestations of informatization in terms of all subsystems of the social system - economic, social, sociocultural, political, legal and scientific. The results have been obtained through the use of methods: abstraction - in determining the essence of the category «informatization of society»; general and special - in establishing the unity of existing approaches in the study of the consequences of the process of informatization for man, nature, society and future generations; system analysis - in determining the components of the social system and the study of the impact of informatization on each of them. Proceeding from the characteristics of informatization as a global, multivector, complex and contradictory process, as well as considering the multifaceted forms of its manifestation, the important task of the state, civil society and the whole world community is to enhancement of positive effects and leveling threats which informatization is producing in all major spheres of socio-economic system to ensure the realization of human needs, the society of nature and future generations.

Keywords: informatization of society, informational economy, information and communication technologies, socio-economic system, positive displays of informatization, negative manifestations of informatization.

\section{References}

1. Zakon Ukrainy «Pro Natsionalnu prohramu informatyzatsii». Stattia 1 [Law of Ukraine on the National Program of Informatization. Vol. 1] (1998). Retrieved from https:// zakon.rada.gov.ua/laws/show/74/98/ [in Ukrainian].

2. Networked Readiness Index. Retrieved from http:// reports.weforum.org/global-information-technology-report/.

3. Ocadchyi, V.V. (2008). Udockonalennia profeciinoi pidhotovky maibutnix vchyteliv zacobamy kompiuterno-orintovanoi cyctemy navchannia [Improvement of professional training of future teachers by means of computer-oriented training system]. Informatsiini texnolohii v ocviti - Informational Extensions in Education, 2, 90-94 [in Ukrainian]. 
4. Mei, K. (2004). Informatsiine cucpilctvo: Ckeptychnyi pohliad [Information society: Ceptic View].- Kiev, 220 p [in Ukrainian].

5. Marchuk, L.P. (2012). Suchasna informatyzatsiia suspilstva ta yii vplyv na innovatsiini protsesy [Modern informatization of society and its impact on innovation processes]

Visnyk ahrarnoi nauky Prychornomoria - Bulletin of agrarian science of the Black Sea region, 1, 37-44 [in Ukrainian].

6. Stadnichenko, O. (2013). Informatyzatsiia yak chynnyk rozvytku suspilstva i derzhavy [Informatization as a factor in the development of society and the state] Retrieved from http:// oldconf.neasmo.org.ua/node/2683/ [in Ukrainian].

7. Rakytov, A.I. (1991). Filosofiia kompiuternoi revoliutsii [Philosophy of the Computer Revolution]. Moskva: Polytyzdat [in Russian].

8. Fedorova, N.Ie. (2018). Sutnist nauky ta yii mistse v suspilnii orhanizatsii [The essence of science and its place in a social organization]. Prychornomorski ekonomichni studii - Black Sea Economic Studies, 26/1, 10-15 [in Ukrainian].

9. Fedorova, N. (2018). Socio-Economic consequences of the Impact of Science on the Development of Society. Modern Science - Moderni veda. Praha, Ceska republica, Nemoros. 1, 19-26.

10. Supyan, V. (2001). Sfera truda v SShA: novyie tendentsii i vyizovyi XXI v. [Labor in the USA: New Trends and Challenges of the XXI Century]. Retrieved from http:// vasilievaa.narod.ru/17_3_01.htm [in Russian].

11. Giljum S, Dittrich M., Lieber M, Lutter S. (2014). Global Patterns of Material Flows and their Socio-Economic and Environmental Implications: A MFA Study on All Countries World-Wide from 1980 to 2009 . Retrieved from http:// www.mdpi.com/2079-9276/3/1/319/pdf.

12. K obschestvam znaniya (2005). Vsemirnyiy doklad YuNESKO. Predislov. K. Matsuura [To knowledge societies. UNESCO World Report. Preface. K. Matsuura] Retrieved from https://www.ifap.ru/library/book042.pdf [in Russian].

13. Ladychenko, T.V (2009). Vsesvitnia istoriia [World History]. Retrieved from https://www.geneza.ua/sites/default/ files/product-images/pdf [in Ukrainian].

14. Bell, D. (1987). The World and the United States in 2013. Daedalus. 116 (3), 1-31.

15. Inozemtsev, V.L. (2000). Tehnologicheskiy progress i sotsialnaya polyarizatsiya $v$ XXI stoletii [Technological progress and social polarization in the XXI century]. Politicheskie issledovaniya - Political studies, 6, 28-39[ in Russian].

16. Forbes Ukraina. Retrieved from http://forbes.net.ua/.

17. Rzhevska, N.F. (2010), Ctratehichni prohnozy shchodo podolannia informatsiinoi nerivnosti $v$ umovakh hlobalizatsii [Strategic forecasts to overcome information inequality in a globalizing environment]. Retrieved from http://jrnl.nau.edu.ua/ index.php/IMV/article/viewFile/3079/3025 [in Ukrainian].

18. Vaynshteyn, G. (2002). Internet kak faktor obschestvennyih transformatsiy [The Internet as a factor of social transformations]. Mirovaya ekonomika i mezhdunarodnyie otnosheniya - World economy and international relations, 7, 16-27 [in Russian].
19. Martyinov, V.A., Dyinkin, A.A. (2001). Mir na rubezhe tyisyacheletiy (prognoz razvitiya mirovoy ekonomiki do $2015 \mathrm{~g}$.) [The world at the turn of the millenniums (the forecast of the development of the world economy until 2015)]. Moscow: Novyiy vek, 592 [in Russian].

20. Global ICT Statistics on Internet Usage, Mobile, Broadband: 1998-2009. Retrieved from http://en.wordpress.com/tag/ ict4d-statistics-2//2010/09/16/globalict-statistics-on-internet-usage-mobile-broadband-1998-2009/.

21. Vzglyadyi voennyih ekspertov SShA na vedenie informatsionnogo protivoborstva (2001) [Views of US military experts on information confrontation]. ZVO, 8, 10-15. Retrieved from http://militaryarticle.ru/zarubezhnoe-voennoe-obozrenie/2001zvo/6727-vzgljady-voennyh-jekspertov-ssha-na-vedenie [in Russian].

22. Osetskyi, V.L. (2009). Zarubizhnyi dosvid zakhystu ta stymuliuvannia rozvytku intelektualnoi vlasnosti v ukraini [Foreign experience of protection and stimulation of the development of intellectual property in Ukraine]. Retrieved from http:// www.nbuv.gov.ua/old_jrn/Soc_Gum/Se/2009_1/09ovfeoi.pdf [in Ukrainian].

23. Fedulova, L.I., Androshchuk, H.O., Khaustov, V.K. (2010). Intelektualna vlasnist u natsionalnii innovatsiinii systemi [Intellectual property in the national innovation system]. National Academy of Sciences of Ukraine, Institute of Economics and Forecasting, 216 [in Ukrainian].

24. Pichkurova, Z.V. (2010). Podolannia problem okhorony prohramnoho zabezpechennia v konteksti yevropeiskoi intehratsii ukraini: vitchyzniani realii ta mizhnarodnyi dosvid Overcoming Software Security Problems in the Context of European Integration of Ukraine: National Reality and International Experience. Naukovyi visnyk Instytutu mizhnarodnykh vidnosyn NAU. Seriia: ekonomika, pravo, politolohiia, turyzm - Scientific herald of the Institute of International Relations of the NAU. Series: economics, law, political science, tourism, 2/2. Retrieved from http:/ /jrnl.nau.edu.ua/index.php/IMV/article/view/3055 [in Ukrainian].

25. Istoriia suchasnoho svitu. Rozdil 15: Postindustrialne suspilstvo: vynyknennia, rozvytok, perspektyvy [History of the modern world. Chapter 15: Post-industrial society: emergence, development, perspectives]. Retrieved from http:// www.history.vn.ua/book/suchasnogo/16.html [in Ukrainian]. 